\title{
Kasvatus, koulutus ja vapaa sivistystyö
}

Aikuiskasvatus-lehden numerossa 4/1982 julkaistiin professori Urpo Harvan artikkeli Tasa-arvo ja kasvatus. Kirjoituksessaan Urpo Harva keskittyi pohtimaan tasa-arvon käsitettä ja määritelmää aikuiskasvatuksen näkökulmasta, mutta artikkelin alussa hän käsitteli myös koulutus- ja kasvatussanojen alaa ja merkitystä sekä vapaan sivistystyön sijoittumista kasvatuksen ja koulutuksen kenttään. Aikaisemmin tästä aiheesta ovat kirjoittaneet ainakin Aulis Alanen (Opistolehti 1/1981), Arvo Ikonen (Opistolehti 7/1980) ja Jukka Tuomisto (Opistolehti 4/1980).

Itsekin olen eri yhteyksissä joutunut pohtimaan näiden termien merkitystä ja suhteita. Seuraavassa joitakin kommentteja keskustelun jatkamiseksi.

Keskustelun lähtökohtana on ollut Aikuiskoulutuskomitean II osamietinnössään (KM 1975/28) esittämä käsitteiden ja termien määrittely, jossa aikuiskasvatus ja aikuiskoulutus asetettiin toistensa synonyymeiksi. Aikuiskoulutus otettiin yleistermiksi ja määriteltiin ohjattujen oppimistilaisuuksien järjestämiseksi aikuisille. Aikuiskasvatus viittaisi samaan toimintakokonaisuuteen pedagogisesta näkökulmasta.

Tätä määrittelyä on arvosteltu: aikuiskoulutuksen on katsottu olevan aikuiskasvatusta suppeamman ja muodostavan aikuiskasvatuksen kokonaisuudesta vain sen osan, joka liittyy muodollista kelpoisuutta tuottavaan koulutukseen. Vapaa sivistystyö ei kuuluisi aikuiskoulutuksen piiriin.

Mielestäni on sinänsä tärkeätä korostaa vapaan sivistystyön omasäätöistä, "yhteiskunnan" ohjailusta riippumatonta luonnetta. Kuitenkin esitetty käsitteenmäärittely ei mielestäni ole aivan yksiselitteinen.

\section{Käsitemäärittelyn perusteet}

Käsitteitä ja niitä kuvaavia termejä voidaan määritellä monin eri perustein. Termejä kasvatus, koulutus ja vapaa sivistystyö määritellessään Urpo Harva käytti kirjoituksessaan ymmärtääkseni kahta eri määrittelyperustetta, joista toista nimitän organisatoriseksi ja toista sisällöllis-tavoitteelliseksi perusteeksi. Nimitykset voisivat varmasti olla paremmatkin, mutta tarkoitan niillä seuraavaa:

Organisatorinen määrittelyperuste tarkoittaa sitä, että käsitteet — tässä tapauksessa kasvatus, koulutus ja vapaa sivistystyö - määritellään luettelemalla ne organisaatio- tai opintomuodot, jotka käsitteen alaan kuuluvat. Sisällöllis-tavoitteellinen määrittelyperuste puolestaan viittaa siihen, minkätyyppisiä tavoitteita ja sisältöjä toiminnalla on.

Professori Harva määrittelee kirjoituksessaan termit kasvatus ja koulutus sekä organisatorisesti että sisällöllis-tavoitteellisesti. Toiminnan sisällön mukaan määriteltynä kasvatus merkitsisi persoonallisuuden kehittämiseen tähtäävää toimintaa (myös itsekasvatusta), koulutus muodolliseen pätevyyteen tähtäävää opetusta. Organisatorisesti määriteltynä kasvatuksen piiriin kuuluvat mm. koti-, koulu- ja korkeakoulukasvatus sekä aikuiskasvatus. Kasvatus nähdään siis yläkäsitteenä. Koulutusta harjoittavat peruskoulut, lukiot ja ammatilliset oppilaitokset sekä korkeakoululaitos, jotka muodostavat koulutusjärjestelmän. Aikuiskasvatusta harjoittavat vapaa sivistystyö, avoin korkeakoulu sekä formaalisen kelpoisuuden tuottamiseen tähtäävä aikuiskoulutus, johon myös avoin korkeakoulu kuuluu silloin, kun tähdätään arvosanojen suorittamiseen. Näistä aikuiskasvatuksen aloista vain viimeksi mainittu eli "aikuiskoulutus" kuuluu koulutusjärjestelmään.

Edellä referoidun määrittelyn mukaan aikuiskasvatus jakautuu sisällön mukaan toisaalta persoonallisuutta kehittävään '"kasvatukseen", toisaalta muodollista kelpoisuutta tuottavaan "'koulutukseen". Aikuiskasvatusta harjoittavat vapaa sivistystyö sekä tietyin poikkeuksin avoin korkeakoulu (organisatorinen määrittely), jotka eivät näin muodoin kuulu koulutusjärjestelmään. Eikö tällainen määrittely ole ristiriitainen juuri vapaan sivistystyön osalta?

Olennainen kysymys on, ymmärretäänkö vapaa sivistystyö organisatorisessa vai tavoitteellis-sisällöllisessä merkityksessä. Toisin sanoen, määritelläänkö vapaa sivistystyö kansanopistojen, kansalais- ja työväenopistojen, opintokeskusten, eräiden kirjeopistojen ja mahdollisesti joidenkin muiden organisaatioiden toimintaan vai muulla tavoin, esimerkiksi juuri kasvatussisällön mukaan? 
Jos vapaa sivistystyö ymmärretään tietyt organisaatiot tai opintomuodot kattavaksi järjestelmäksi, on selvää, että sen piirissä harjoitetaan sekä "kasvatusta" että "'koulutusta" Urpo Harvan tarkoittamassa sisällöllisessä merkityksessä. Esimerkiksi kansanopistojen perusoppijaksojen opiskelijoista lähes puolet opiskelee linjoilla, joiden opetus on järjestetty noudattaen peruskoulun tai lukion opetussuunnitelmaa tai on selkeästi keskiasteen ammatillista koulutusta.

Jos vapaa sivistystyö taas ymmärretään sisällöllisenä käsitteenä - siis persoonallista kasvua edistävänä kasvatuksena erotukseksi muodollista kelpoisuutta tuottavasta koulutusta - jäisi osa kansanopistojen sekä kansalaisopistojen toiminnasta vapaan sivistystyön ulkopuolelle.

Vapaan sivistystyön piirissä annetaan siis monen tyyppistä kasvatusta: sekä persoonallisuuden kehittämiseen tähtäävää "kasvatusta", että yleissivistäviin ja ammatillisiin tutkintoihin valmentavaa "'koulutusta"'. Vastaavasti esimerkiksi peruskoulu, jonka muodollisena tehtävänä on oppivelvollisuuden edellyttämän opetuksen antaminen, pyrkii kasvatuksessaan kehittämään myös oppilaiden kokonaispersoonallisuutta. Toisin sanoen, samalla kun peruskoulu muodollisesti on "koulutusta" tähdätessään oppivelvollisuuden edellyttämän opetuksen antamiseen, se sisältää persoonallisuutta kehittäviä aineksia eli "kasvatusta".

Ei siis ole aivan riidatonta määritellä eri organisaatioiden toimintatavoitteen ja sisällön mukaan kasvatukseksi tai koulutukseksi.

\section{Eräs mahdollisuus}

Seuraavassa esitän vielä yhden mahdollisuuden näiden sanojen merkityksen ja suhteen määrittelemiseen.

Kasvatus voidaan määritellä yksilöiden tai ryhmien kasvun ohjaamiseksi asetettujen tavoitteiden suunnassa. Tällä tavalla määriteltynä kasvatus on laaja-alainen käsite, jonka piiriin ymmärtääkseni kuuluu kaikki eri-ikäisten ihmisten erilaisin tavoittein ja erilaisissa yhteyksissä tapahtuva kasvun ohjaus eli kasvatus.

Mitä sitten olisi koulutus? Eräs tapa on määritellä koulutus "institutionalisoiduksi", kasvatukseksi eli koulutusjärjestelmän piirissä annettavaksi kasvatukseksi. Koulutusjärjestelmä puolestaan voịtaisiin määritellä kasvatukseen erikoistuneeksi ja sitä varten järjestetyksi instituutioiden, oppilaitosten sekä niiden sisäisten opetus- ym. järjestelyjen muodostamaksi kokonaisuudeksi.

Mikäli edellä esitetty hyväksytään, aikuiskasvatus olisi yläkäsite, joka kattaa aikuisten kasvun ohjauksen sekä koulutusjärjestelmän piirissä että muualla. Koulutus olisi kasvatuksen institutionaalinen muoto. Tässä mielessä vapaa sivistystyökin kuuluisi koulutusjärjestelmän piiriin; onhan sitä varten olemassa opetussuunnitelmia, opettajia, opetustiloja ja -välineitä ja valtionapujärjestelmiä.

Tähän käsitejärjestelmään sopii mielestäni hyvin Aikuiskoulutuskomitean määritelmä aikuiskoulutuksesta: ohjattujen oppimistilaisuuksien järjestäminen aikuisille. Lisäksi voitaisiin ottaa huomioon myös muu aikuiskasvatus, se jota tapahtuu vapaan sivistystyön, avoimen korkeakoulun, iltakoulujen, työllistyyskoulutuksen, työelämän henkilöstönkoulutuksen ym. aikuiskoulutuksen ulkopuolelle esimerkiksi yhteiskunnallisessa toiminnassa ja kulttuuritoiminnassa. Koulutukseksihan sitä ei äsken esitettyjen kriteerien mukaan voida nimittää, mutta osittain kaiketi kasvatukseksi. 